\title{
Example of integrated use of surface and groundwater resources in irrigation in Croatia
}

\author{
Lidija TADIĆ
}

Faculty of Civil Engineering, University of Osijek, Drinska 16a, 31000 Osijek, Croatia; e-mail: ltadic@most.gfos.hr

\begin{abstract}
Irrigation in Croatia was until recently a neglected measure in food production, especially in continental part of the country. Development of drainage system in the last fifty years was more important due to the problems caused by floods and excess water in the fields. In the last decade the hydrological regime has been changed and drought events became as frequent as flood events, causing even more damage. Future development of agriculture in the northern counties of Croatia depends on the introduction of new, profitable crops which imply irrigation as an essential factor of future social and economic growth.

The first step in the implementation of irrigation was the development of National Irrigation Master Plan as a framework for future activities.

According to the recommendations of the National Master Plan all counties have created County Irrigation Plans considering local natural conditions, social and economic background.

This paper is going to present how is that process of integrated water resources management developing in the continental part of Croatia on the example of Osijek County Irrigation Plan located in the Danube river basin.
\end{abstract}

Key words: irrigation plan, water resources, integrated water management, environment

\section{INTRODUCTION}

County Irrigation plans for each county in Croatia are based on the National Irrigation Master Plan (Nacionalni projekt..., 2005). They are going to be basic planning documents with the main goal of evaluating natural resources, in quantitative and qualitative sense, as well as defining the area with priorities in irrigation development and assessing social and economic benefits.

According to the National Irrigation Master Plan, great care must be placed on the environmental protection. All areas under protection must be isolated in the sense of irrigation development. According to the Law of Nature Protection (2005) intensive agriculture should not be practiced in the areas under any level of protection. It includes national parks, nature parks, nature reserves, etc. 
The second type of protection refers to the water sanitation zones of public water supply well yards. National regulations define three sanitation zones in the continental part of the country and four sanitation zones in the region along the Adriatic coast. In the first two intensive agriculture, including irrigation, is strictly forbidden, only ecological or environment-friendly agriculture is allowed. In the other two zones implementation of irrigation is allowed only in special cases and it is necessary to define environmental impact assessment.

In this initial phase of irrigation implementation, the general recommendation is not to develop irrigation systems in all water sanitation zones. In the continental part of the country, in five counties that were analysed, almost 200.000 ha belong to protection zones of the well yards. Most of that area belongs to the agricultural land.

These rather heavy regulations are made in order to prevent water mining and endangering major public water supply resources in one respect, and they also protect valuable natural resources and the wildlife.

In this way basic idea of sustainable water management is respected. Agriculture is a great water consumer, but it must not endanger other water users and the environment. Besides, in order to minimize possible side effects of irrigation on the environment monitoring system of surface and ground, water resources must be established. Extension of monitoring system depends on the size of irrigated area.

Analysis potential water resources are compared to the water deficit and environmental limitations, leading to the map of priorities in irrigation implementation. Figure 1 shows the schematics of irrigation priorities mapping the whole country.

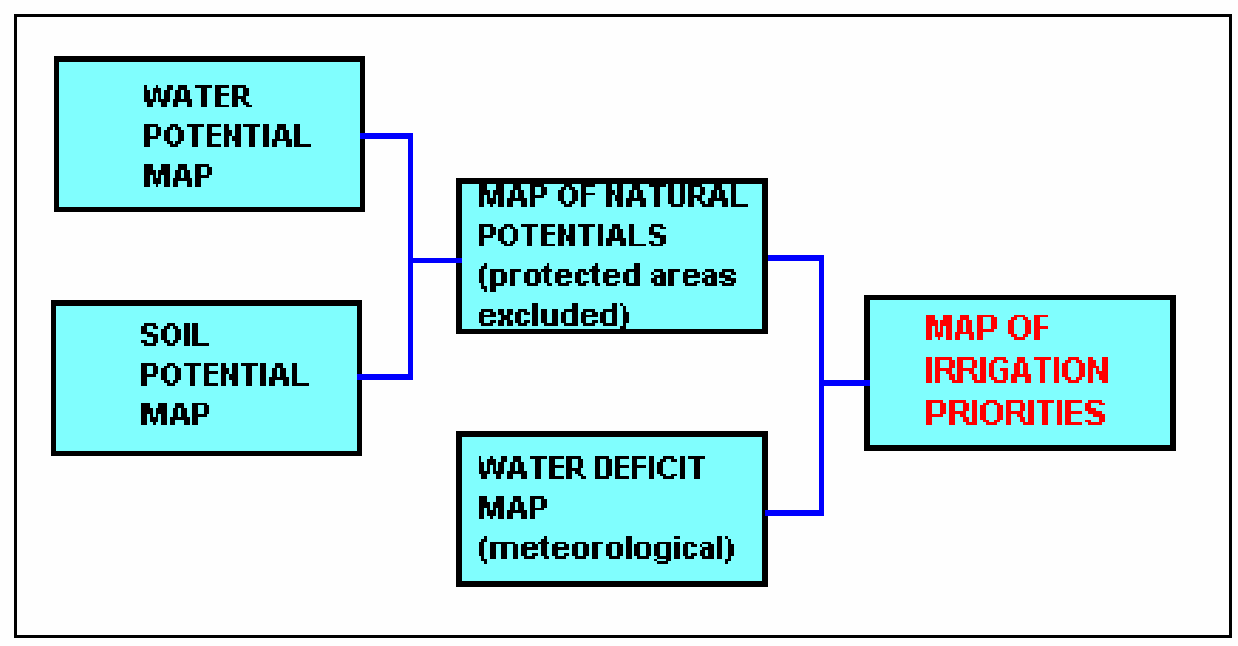

Fig. 1. Scheme of irrigation priorities 
The model includes two matrixes: one for the development of maps of natural potentials, and the other, mapping water needs or water deficit. The result of multicriteria analysis is a map of irrigation priorities on the county level. In the second phase of multi-criteria analysis economic and social criteria were considered.

\section{CHARACTERISTICS AND METHODS}

Osijek County Irrigation Plan (2006) is very important for the agricultural development of Croatia due to the fact that $8.6 \%$ of total agricultural land is located in this county what is around 151.000 ha. Besides, this Plan was very complex because the geographic position of the county on the two large river basins, Sava and Drava, which are both part of the Danube river basin.

The main purpose of the irrigation plan development is to define directives, criteria, and limitations of irrigation development in present and future conditions of agricultural production and available natural resources.

\section{NECESSITY OF IRRIGATION}

Water deficit in the vegetation period appears to be more frequent in the last 15 years. Particularly in the years 1992, 1995, 1998, 2000, and 2003 drought damages in agriculture were extensive. Meteorological, agricultural, or hydrologic drought can be estimated by different methods. This phenomenon was analysed by using meteorological data from the period between years 1951-2000, measured at the Osijek meteorological station.

Meteorological drought is defined as a precipitation deficit when there is a prolonged period with less than average precipitation (TADIĆ et al., 2007) In the observed fifty-year period there are even more years, $66 \%$ or 33 years with total annual precipitation higher than average but there is ascendant trend of annual water deficit (Fig. 2).

Water deficiency in the vegetation period implies yield reduction. Yield analysis of the most common crops show significant decrease in dry years compared to the years with average precipitations. Table 1 shows data of average and extreme water deficit and yield reduction caused by these insufficient moisture conditions.

For the irrigation planning hydrological drought has great importance. It appears when the water resources that are available in different sources (rivers, lakes and ground water reservoirs) fall below average value for the longer time period.

There is no reliable and unique methodology for drought identification but there are numerous drought indicators based on precipitation, water level, or discharge measurements. They estimate intensity, duration, or strength of the drought 


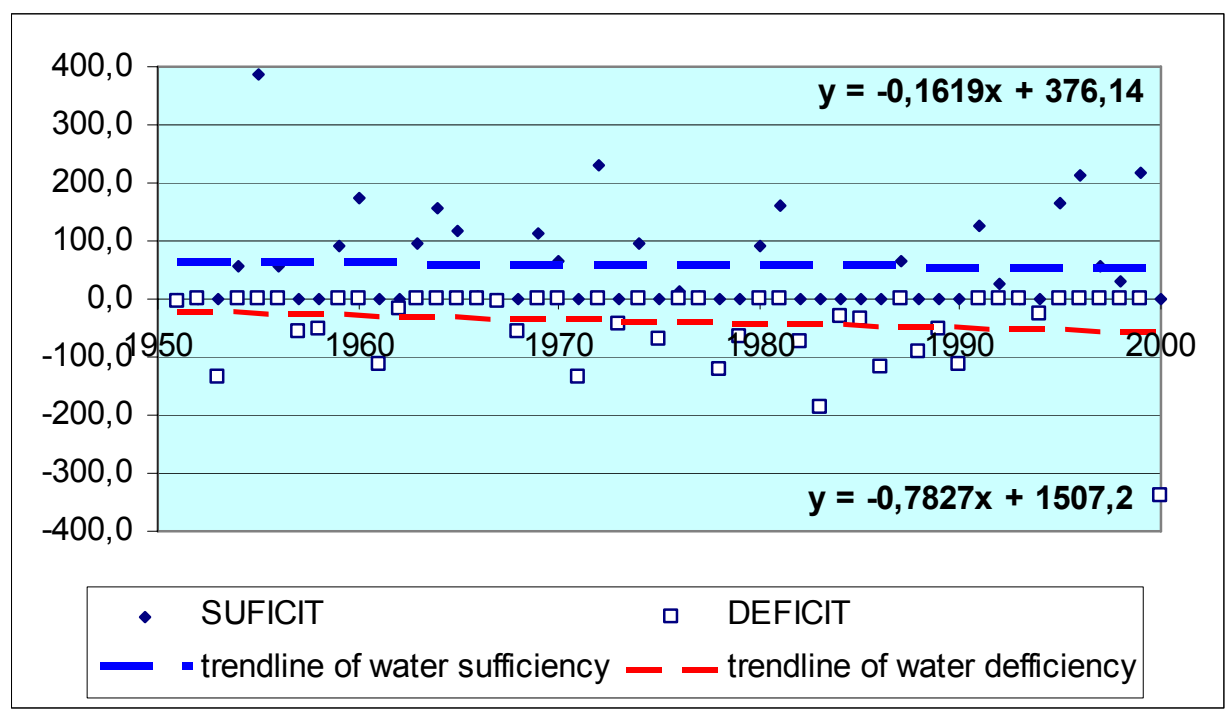

Fig. 2. Total annual precipitation in the period from 1951-2000 compared to the average

Table 1. Water deficit and yield reduction in average and dry years observed depending on soil conditions

\begin{tabular}{l|c|c|c|c|c|c}
\hline \multirow{2}{*}{\multicolumn{1}{c|}{ Crop }} & \multicolumn{2}{|c|}{ Water deficit, mm } & \multicolumn{4}{c}{ Yield reduction, \% } \\
\cline { 2 - 7 } & $\begin{array}{c}\text { average } \\
\text { year }\end{array}$ & dry year & \multicolumn{2}{c}{ light soil } & \multicolumn{2}{c}{ heavy soil } \\
\cline { 4 - 7 } & $\begin{array}{c}\text { average } \\
\text { year }\end{array}$ & dry year & $\begin{array}{c}\text { average } \\
\text { year }\end{array}$ & dry year \\
\hline Corn & 187 & 287 & 35.4 & 61.5 & 27.1 & 54.4 \\
Sugar beet & 246 & 349 & 36.7 & 58.7 & 29.1 & 52.6 \\
Tomato & 188 & 260 & 37.3 & 54.8 & 29.8 & 47.9 \\
$\begin{array}{l}\text { Apple without cover } \\
\text { crop }\end{array}$ & 180 & 294 & 25.7 & 49.4 & 20.8 & 41.8 \\
\hline
\end{tabular}

period (BONACCI, 2003) Reliability of these indicators depends on the length of hydrological series and their applicability in specific climate conditions.

Two methods were used for the drought identification in Osijek County: standardized precipitation index (SPI) and deciles method applied on monthly precipitation data. Results have been compared with two other counties in other regions of Croatia (Zagreb County on the north-western part of the country and Split County in the south).

Table 2 shows the results of drought analysis by SPI method. Positive values show more or less humid characteristics of the region and negative values present more or less arid characteristics. 
Table 2. Drought evaluation by SPI method

\begin{tabular}{lll}
\hline \multicolumn{1}{c|}{ Meteorological station } & SPI & \multicolumn{1}{c}{ Evaluation } \\
\hline Osijek County & -4.4 & extremely dry \\
Split County & -8.8 & extremely dry \\
Zagreb County & 0.06 & near normal \\
\hline
\end{tabular}

Table 3 presents drought evaluation by deciles. The majority of monthly precipitation in the observed period can be evaluated as being "below average" and "much below average".

Table 3. Drought evaluation by deciles method

\begin{tabular}{c|c|l}
\hline Meteorological station & Percentage & \multicolumn{1}{c}{ Evaluation } \\
\hline Osijek County & 0 & much above average \\
& 0 & above average \\
23 & average \\
56.5 & below average \\
& 20.5 & much below average \\
\hline
\end{tabular}

Even though these methods give only an estimation of drought severity in Eastern Croatia, the fact is that frequency increases together with damages caused by water deficit.

\section{POTENTIALS FOR IRRIGATION IMPLEMENTATION}

Analysis of input data for the Osijek County Irrigation plan has shown natural and technologic potentials that can be used and developed in adequate and sustainable way. Furthermore, there is a number of limitations that cannot be neglected or diminished, particularly in environmental sense.

\section{Soil and agricultural potentials}

Total agricultural area in the County is 277848 ha. Part of it belongs to the Park of nature and well yards used for the public water supply and intensive agricultural production is not allowed. The rest of the agricultural land, consisting of $150768 \mathrm{ha}$, can be considered as more or less suitable for irrigation according to physical and chemical properties, environmental characteristics and drainage conditions. This type of soil evaluation was made in order to avoid negative irrigation affects on the soil and to minimize the costs of land reclamation. In Table 4 there are classes of soil suitability of total agricultural land. 
Table 4. Soil suitability for irrigation

\begin{tabular}{lrl}
\hline \multicolumn{1}{c}{ Class of suitability } & Area, ha & \multicolumn{1}{c}{ Reclamation measures } \\
\hline Excellent (P-1) & 20912 & None \\
Suitable (P-2) & 99366 & Basic agrotechnical and hydro-technical \\
Restrictively suitable (P-3) & 30490 & Additional agrotechnical and hydrotechnical \\
Total & 150768 & \\
\hline
\end{tabular}

Being situated in a traditionally agricultural region, the County reaches a relatively high level of agricultural production with regard to land organization, as well as production technology, mechanization, and application of scientific and contemporary methods in agricultural production. Main characteristics of present crop production are as follows: orientation toward extensive food production and small number of cultivated crops that are present on large acreages, low presence of fruit and vegetables, and inadequate use of quality land resources suitable for production diversification (TADIĆ et al., 2007) By introducing irrigation, the conditions for producing more profitable, water-deficiency sensitive crops will be realized and the present agricultural potential will be largely strengthened.

\section{Water resources potential}

In the County area, there are two rivers with the highest liquid-water content, exhibiting a glacial regime suitable for water intake during vegetation period (Drava and Danube), and their water content is well above region's needs. Other surface water resources, despite a well-developed hydrographic network, have far less potential at present state of water management because during summer, when the crops' water needs are at its peak, they have minimum discharges or even dry up. Osijek County Irrigation Plan includes the construction of 32 multipurpose accumulations, located mostly on outer highland parts of the County, whose main purpose is, aside from preventing floods, the use of irrigation water. Beside accumulations, Area plan schedules the construction of Drava water-step, by which the water potential of both the river and the shoreland would increase substantially. Analyses of underground water availability are limited to renewable groundwater resources. Considering the fact there is a sufficient quantity of surface waters, groundwater intake is planned only for those agricultural areas where there is no possibility of surface water intake, and also outside of sanitary protection zones.

\section{Water quality potential}

When discussing surface and groundwater irrigation potential, the recommendations for irrigation water quality assessment, FAO Publication "Water quality for agriculture" (AYERS and WESTCOT, 1985) shall be followed. Water quality analysis of potential irrigation water sources, great rivers, and underground waters has 
shown satisfactory suitability for irrigation purposes. Drava and Danube waters have no application limitations with respect to most parameters analyzed (electrical conductivity, specific ion concentration, concentration of heavy metals, and nitrogen level). There is a low to medium limitation regarding the risk of lower infiltration capability, but the existence of a significant limitation considering the amount of suspended matter should be noted, especially when dealing with water-grips and chosing irrigation devices. FAO recommendations used for biological parameters do not give guidelines nor borderline values. According to this set of parameters, the waters of Drava and Danube fall into II. or III. type, and judging from the Directive on Water Classification (1998) type III waters are suitable for agricultural use. Quality parameters for surface waters found in accumulations exhibit no limitations regarding irrigation application.

Underground waters are characterized by a medium or high salinity risk and low alkaline risk. Other criteria suggest no additional risks in irrigation application. Very low nitrate-level index is of great importance (mainly under $1 \mathrm{mg} \mathrm{N} \cdot 1$ ), especially considering dominantly agricultural environment with incorporated livestock production.

\section{LIMITATIONS OF IRRIGATION IMPLEMENTATION}

Recorded limitations imply parts of the County in which irrigation in agriculture is forbidden due to some degree of protection, as well as those parts in which, for one reason or another, irrigation is not possible. Beside these physical limitations, those stemming from legal acts and international obligations shall be noted as well.

Protected areas

In the County area there is Nature park Kopački rit, an exceptionally valuable and in biological sense uniquely diverse swamp area protected from 1967 and listed in 1993 on the List of internationally significant swamps (the Ramsar Convention, ratified in 1995). It is situated in the south-eastern part of Baranja region, between rivers Drava and Danube, taking the area of 22970 ha. Inside the Nature park Kopački rit there is around 2000 ha of plowfield areas on which only ecological agriculture is allowed. In the protection zone area, which is around 26000 ha (64 246 acres) large, the plan is to keep traditional, extensive agriculture with tendency of gradual transformation towards ecological production. Outside the protection zone intensive agricultural production is allowed, together with irrigation application (PLETIKAPIĆ et al., 2003). In line with this plan, the whole Nature park area is excluded from the County irrigation plan although irrigation application in protected areas is allowed with consent of proper authorities (Law of Nature Protection). 
Public water supply areas

There are 34 pumping zones for bulic eater supply in the County, their protection zones covering the area of 100194 ha. The building of new water pump areas is scheduled by County's area plan, together with closing down of some existing ones, which would lower the limitations regarding area protection (Regulations..., 2002).

\section{Mined areas}

Presently, there is 20820 ha of land in the County, 30\% of which is arable, that are thought to be mined and are thus unsuitable for irrigation. When the conditions become more appropriate, these areas will be possible to integrate into the system, depending on their irrigation suitability.

Finally, Figure 3 shows areas on which it is temporarily or permanently impossible to conduct irrigation projects and areas on which irrigation development is possible with respect to the soil suitability.
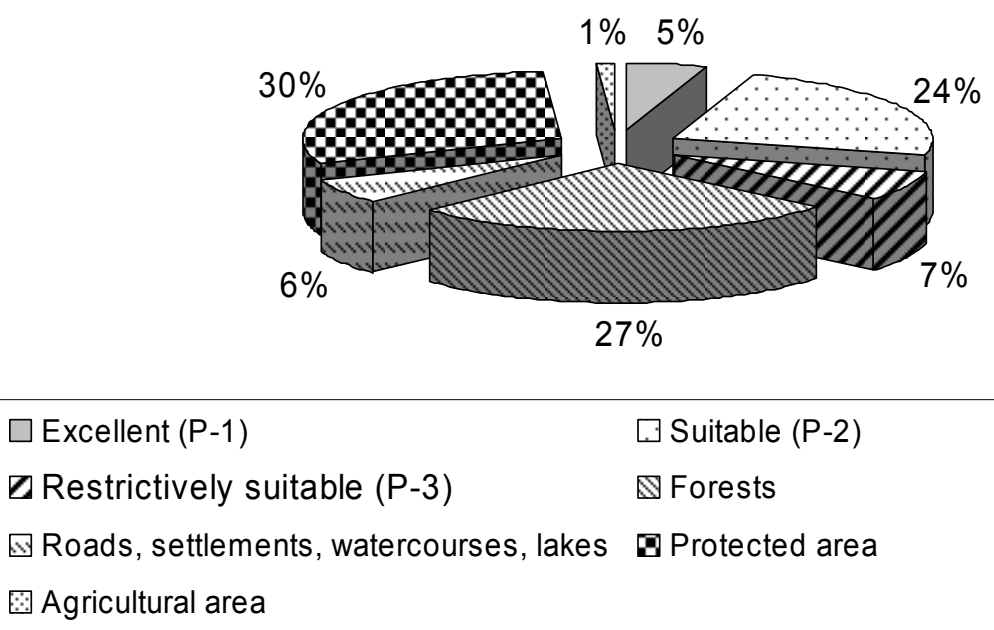

Fig. 3. Territorial limitations and potentials for irrigation

\section{Institutional and legal limitations}

During the making of County's irrigation plan, all factors relevant for irrigation problem were taken into consideration, including existing laws and strategies, as well as international conventions. According to Convention on the Protection and Use of Transboundary Watercourses and International Lakes - Helsinki Convention (1996), it is obligatory to maintain sustainable water resources management with regard to the ecosystem, i.e. all parties involved must take all the necessary measures to ensure environment-friendly and rational exploiting of trans- 
boundary watercourses. Convention on Cooperation for the Protection and Sustainable Use of the Danube River (1996) defines that water intake should be used to attain the basic goal, i.e. sustainable and just water management including preservation, improvement, and rational exploiting of surface and underground waters in the Danube basin. The Convention also regulates the monitoring of water balance and water quality. These conventions limit the possibility of surface water intake only on the contribution of waters on Croatia's territory. The directives of these conventions are integrated into the Strategic Basis for Water Management in Croatia (2005), as well as the National Irrigation Master Plan.

\section{WATER BALANCE}

County's total annual liquid water content is significant and shows great potential for the development of irrigation. Drava and Danube have the greatest share and there are no limitations in irrigation water intake with respect to these two rivers. Other potential water sources are highland accumulations, natural and artificial waterstreams, and underground waters.

The County Plan implies the use of around $5-15 \mathrm{~m}^{3} \cdot \mathrm{s}^{-1}$ of water, which does not represent a significant quantity considering the water flows during summer months.

Table 5 shows the sources of irrigation water together with hydrological characteristics and irrigation water quantity assessment.

Table 5. Potential irrigation water sources-assessment of water spanning possibility

\begin{tabular}{|c|c|c|c|c|}
\hline & $\begin{array}{l}\text { Water } \\
\text { resource }\end{array}$ & $\begin{array}{l}\mathrm{Q}_{\text {aver }} \\
\mathrm{V}_{\text {aver }}\end{array}$ & $\begin{array}{l}\text { Volume during } \\
\text { vegetation } \\
\text { period }\end{array}$ & Note \\
\hline Great rivers & $\begin{array}{l}\text { Drava } \\
\text { Danube }\end{array}$ & $\begin{array}{l}550 \mathrm{~m}^{3} \cdot \mathrm{s}^{-1} \text { (Osijek) } \\
2800 \mathrm{~m}^{3} \cdot \mathrm{s}^{-1} \text { (Batina) }\end{array}$ & $40-120 \cdot 10^{6} \mathrm{~m}^{3}$ & no limitations \\
\hline $\begin{array}{l}\text { Highland } \\
\text { accumulations }\end{array}$ & $\begin{array}{l}\text { Borovik } \\
\text { Lapovac II } \\
32 \text { planned } \\
\text { accumulations }\end{array}$ & $\begin{array}{l}7.9 \cdot 10^{6} \mathrm{~m}^{3} \\
2.4 \cdot 10^{6} \mathrm{~m}^{3} \\
\approx 95 \cdot 10^{6} \mathrm{~m}^{3}\end{array}$ & $30.3 \cdot 10^{6} \mathrm{~m}^{3}$ & $\begin{array}{l}\text { assessment of use for } \\
\text { irrigation pur-poses } \\
\text { for } 30-60 \% \text { of } \\
\text { accumulation volume }\end{array}$ \\
\hline $\begin{array}{l}\text { Small water- } \\
\text {-streams and } \\
\text { artificial } \\
\text { channels }\end{array}$ & $\begin{array}{l}\text { - mostly overdi } \\
\text { - used for trans } \\
\text { - hydrotechnica }\end{array}$ & $\begin{array}{l}\text { d during vegetation } \mathrm{p} \\
\text { orting water } \\
\text { structures are needed }\end{array}$ & iod & \\
\hline Ground water & $\begin{array}{c}\text { - renewable } \\
\text { resources }\end{array}$ & $\begin{array}{l}90.000 \mathrm{~m}^{3} \cdot \mathrm{year}^{-1} \\
\cdot \mathrm{km}^{-2}\end{array}$ & $65 \cdot 10^{3} \mathrm{~m}^{3}$ & $\begin{array}{l}\text { use possible if there } \\
\text { are no other priorities }\end{array}$ \\
\hline
\end{tabular}




\section{RESULTS}

According to the present state of land organization and water availability with regard to the level of construction of hydrotechnical facilities it is possible to irrigate about 3000 ha of agricultural land right now. Potential agricultural plots are grouped near water sources (beside waterstreams or downstream from already built accumulations Lapovac II and Borovik). In the past few years underground waters were predominantly used - by drilling wells and using it directly on the parcel while applying sprinkler irrigation method or by localized irrigation. Unfortunately, this sort of water use does not have a project basis and the number of these procedures, as well as the quantity of water taken remain unknown. In accordance with the National Irrigation Master Plan, this sort of approach is to be as minimized as possible by cofinancing water intake construction and by supplying water directly to the parcel. The share of the state's subsidy depends on the property size. This way all planned interventions would be evidented, and they would be required to have all the necessary papers (documentation).

Figure 4 shows lands which are viable for irrigation without major further investments with respect to the present level of irrigation system construction, as well as the soil irrigation suitability.

In the analysis of possibility of hydromelioration system development in the County area, two options will be considered:

1) irrigation development based primarily on the construction of accumulations in the highland area of the basin,

2) irrigation development with the exploitation of multipurpose Osijek water-step and its water potential.

The main idea behind these two approaches is based on "primary use of surface waters", while the underground water use is recommended as a secondary source on the soils of required suitability, if there is no possibility of water intake from accumulations or open waterstreams.

When discussing the first possibility for irrigation, the construction of highland accumulations is of great importance. According to the Osijek County Irrigation Plan, the construction of 32 accumulations is planned, which have a total volume of $95 \times 10^{6} \mathrm{~m}^{3}$, together with the existing accumulations. It is estimated that up to 30.000 ha of land can be irrigated in this way.

The limiting factor regarding this solution is the great cost of accumulation construction together with all hydrotechnical facilities needed. According to the map of irrigation-suitable land, the construction of 8 accumulations is a priority.

The use of waterstream waters is based on the exploitation of Drava and Danube waters. This exploitation can be direct, or the waters can be streamed into smaller rivers or artificial channels. 


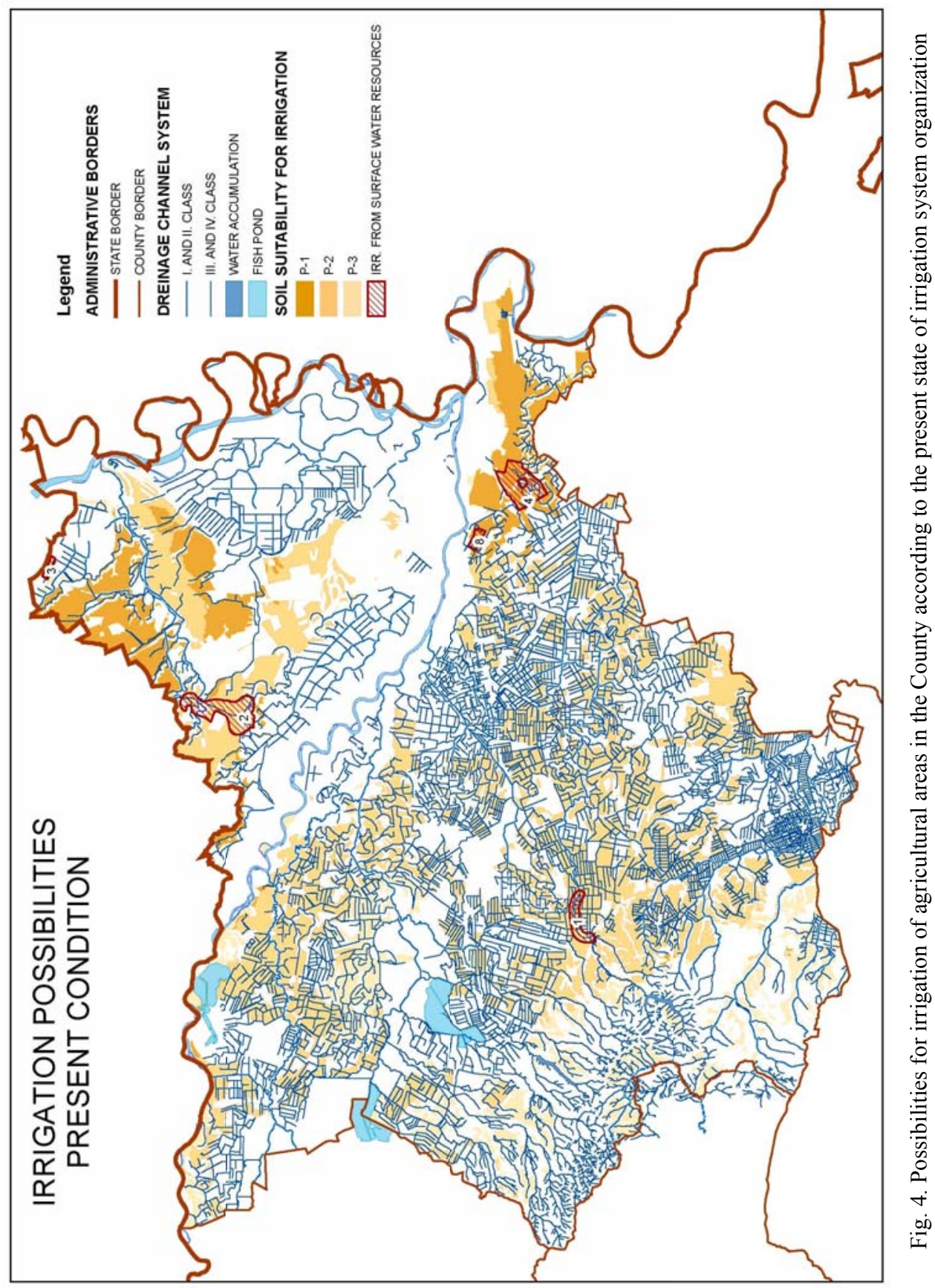




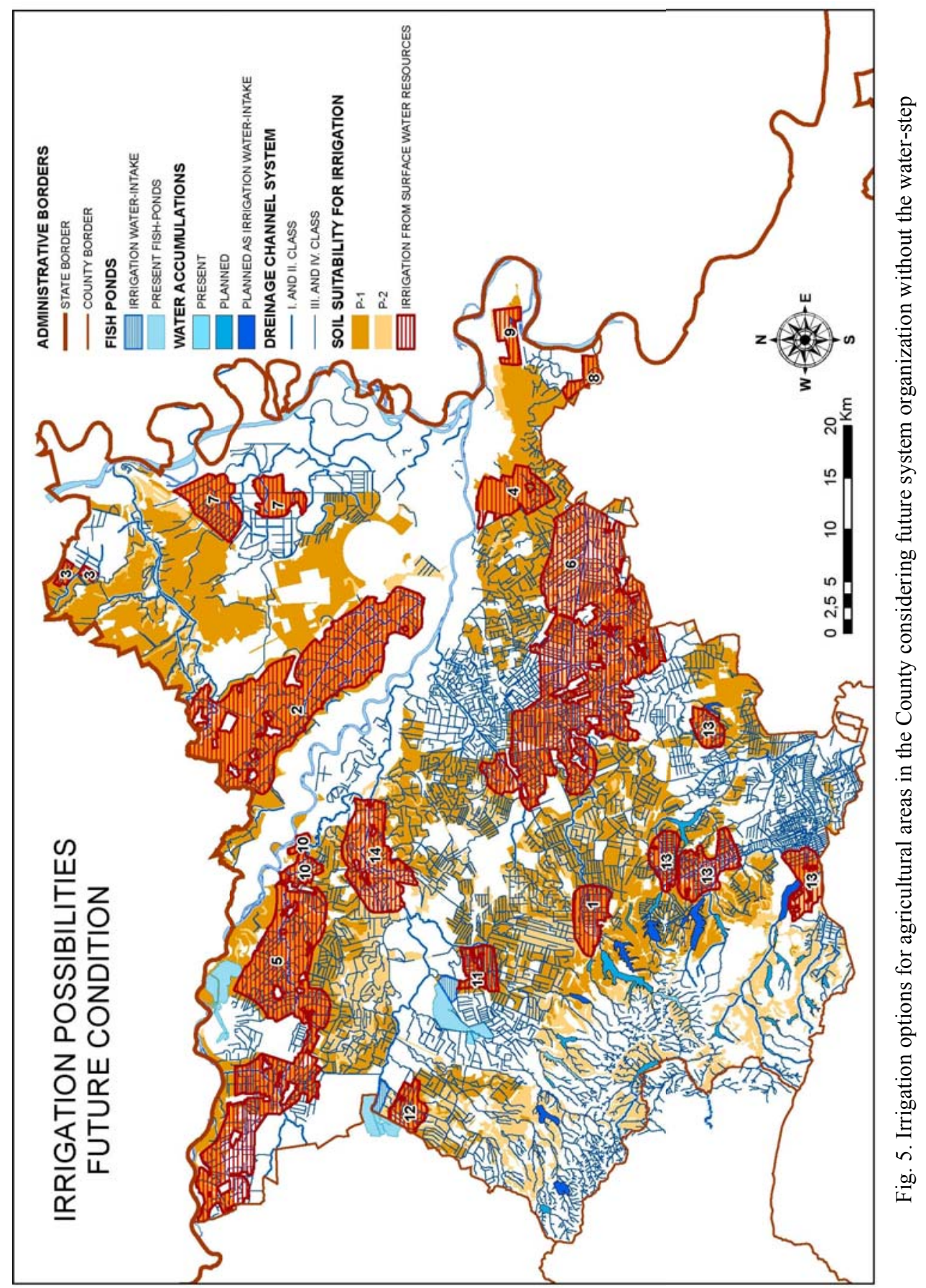


The use of underground waters is planned for lands belonging to excellent and good suitability classes, which do not have the possibility of water supply from surface waterflows. Figure 5 shows irrigation possibilities with respect to the first option.

The second option for irrigation system development takes into consideration the possibility of exploiting Osijek water-step's water potential with chainage at 33 +100 of Drava River, average height being 4,0m. This option does not affect total size of agricultural areas suitable for irrigation in the first option, but the construction of Osijek water-step enables simpler and less expensive technical solutions. The construction of great water intakes from river Drava would be avoided because, by raising water level upstream from the water-step, it becomes possible to direct the flow of water into the existing surface drainage hydromelioration system with the use of gravity. The system would require major or minor reconstruction and the construction of system management facilities. The exploitation of underground waters does not differ from the first option.

\section{ENVIRONMENT PROTECTION MEASURES}

With regard to protecting the environment, areas that are under any degree of protection or those sensitive of natural imbalance shall not be included in irrigation suitability assessment. These are Nature Park Kopački rit, protection zones around waterpumps, and areas threatened by water erosion. These are preliminary protection measures undertaken on the areas where intensive agricultural production is not allowed.

Applying irrigation can cause a number of undesirable consequences if employed inadequately or in unfavourable conditions (TADIĆ and BAŠIĆ, 2007). Consequences are reflected on the flora, the soil, as well as surface and underground waters. The greatest risks with applying irrigation appear due to unfavourable physical and chemical water properties, overextensive irrigation, intensive fertilization and plant protection or intake water from natural resources. Consequences on the environment can be permanent if they are not predicted, if the state of the environment is not monitored, and if measures to minimize these consequences are not introduced.

In the County area water quality is monitored by sampling on 15 stations in total. It will be necessary to broaden monitoring locations and parameters once irrigation is introduced. The analysis of irrigation water quality from the smaller rivers has shown inadequacy of the existing set of parameters, i.e. it does not involve parameters crucial for assessing irrigation water suitability - natrium, calcium, and magnesium (TADIĆ, 2007). 
There is similar situation concerning quality assessments for underground waters that are done for drinking water pump stations. These assessments should determine whether a particular type of water is suitable for drinking.

Table 6 shows the suggestion for surface and underground water monitoring depending on the size of the irrigation system.

Table 6. Suggestion for surface and underground water monitoring

\begin{tabular}{|c|c|c|}
\hline Size of irrigation, ha & Surface water monitoring & Ground water monitoring \\
\hline $0-50$ & \multicolumn{2}{|c|}{$\begin{array}{l}\text { Survaillance through the existing surface and underground water monitor-ing } \\
\text { system }\end{array}$} \\
\hline $50-100$ & $\begin{array}{l}\text { Minimum one location downstream } \\
\text { from the irrigation area with observa- } \\
\text { tions taken twice a year (unless there } \\
\text { is an existing station in the proximity) }\end{array}$ & $\begin{array}{l}\text { Minimum one piezometer } 12 \mathrm{~m} \\
\text { deep (at most) from which samples } \\
\text { for water quality assessment are } \\
\text { gathered twice a year }\end{array}$ \\
\hline$\geq 100$ & $\begin{array}{l}\text { One location every } 100 \text { ha with } \\
\text { observations twice a year }\end{array}$ & $\begin{array}{l}\text { One piezometer every } 100 \text { ha with } \\
\text { observations twice a year }\end{array}$ \\
\hline
\end{tabular}

Unlike water monitoring, systematic soil monitoring is not established. County database of soil quality is under construction, and it represents the basis for establishing soil monitoring. County's irrigation plan schedules the introduction of annual soil analysis for every land user applying irrigation, which should be cofinanced by the County or the State. Parameters needing assessment are: phosphorus and potassium content in the soil, $\mathrm{pH}$ reaction of the soil, as well as nitrogen, calcium-carbonate, and humus percentage.

\section{PROJECT EXPENSES ASSESSMENT}

Cost assessment was taken for the area of $15000 \mathrm{ha}$, which is the maximum that can be achieved by 2015 . The analysed expenses are as follows:

- water intakes - connecting pipelines, reconstruction of existing barriers and building of new ones, water management facilities built on areas suitable for irrigation,

- building of accumulations in the County area, that are a priority for irrigation,

- construction of hydrotechnical and agrotechnical meliorations,

- supplying irrigation equipment in production areas.

Assessment of expenses was done in accordance with elements of National Irrigation Master Plan and applied in the County. Total costs for the area of 15000 ha are estimated at over 70 million euros $\left(4700 € \cdot \mathrm{ha}^{-1}\right)$, bearing in mind that the construction of necessary facilities and infrastructure provides basis for the irrigation of much larger areas than planned. 
Figure 6 shows the costs of Osijek County Irrigation Plan application by the year 2015 .

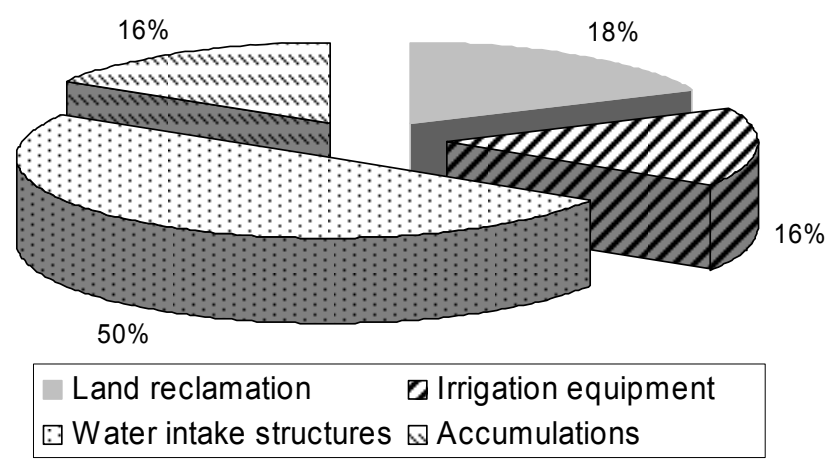

Fig. 6. Cost structure of Osijek County Irrigation Plan application by the year 2015

\section{CONCLUSION}

According to the National Project for Irrigation and Agricultural Land Waters Management in the Republic of Croatia, the making of county plans has the highest priority. The Irrigation Plan of Osijek County has been adopted and it gives the survey of all water and land resources in the County, technical solutions for irrigation implementation, soil protection measures, and the assessment of socio-economical effects of irrigation.

Figure 7 shows the planned dynamics of irrigation system development by the year 2015. To what extent will the planned development be realized depends on a variety of factors, primarily financial, but also on the degree of development of agricultural products market.

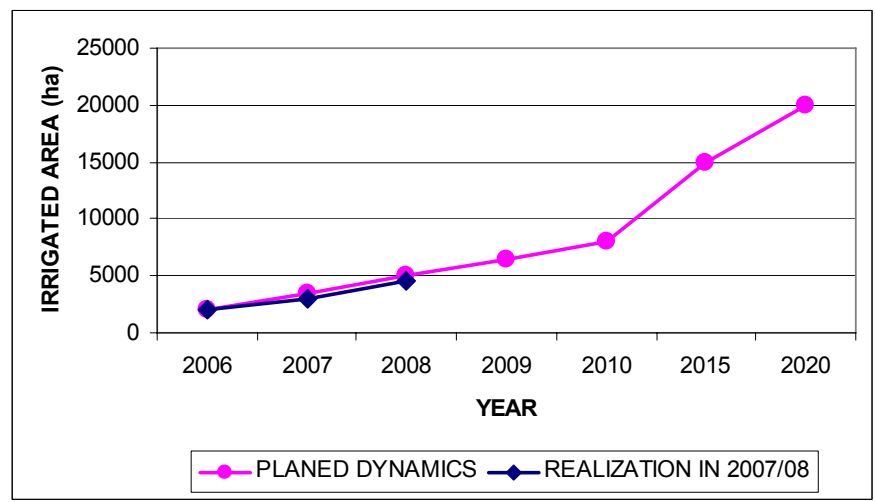

Fig. 7. Dynamics of irrigation system development by the year 2015 
According to the planned dynamics of irrigation development, 15000 ha of land could be irrigated by the year 2015. To what extent will this plan be realized depends primarily on the economical conditions. During 2007 on about 1000 ha of agricultural land irrigation system has been completed and on further 1500 ha is in preparation for 2008.

Besides, County Irrigation plan defines a number of long-term activities, some of which have already started:

- financial impetus of making project documentation and cofinancing of irrigation project realization, along with defining clear criteria concerning the latter,

- establishment of permanent County commission for monitoring, implementing, and controlling irrigation,

- control of irrigation on the field together with the making of maps and land registry of irrigated lands, as well as the definition of " 0 " land state,

- establishment and application of annual irrigation programs,

- encouragement of faster mine clearance of agricultural areas,

- continued application of III. and IV. order canal network maintenance,

- launch of the initiative for altering County's Area Plan regarding sanitary protection zones,

- encouragement of cooperation with institutions handling irrigation,

- definition of the extended monitoring system, primarily together with "Hrvatske vode",

- establishment of irrigation department with agricultural-advisory office,

- establishment of a pilot-project

The establishment of a pilot-project has an important role in further irrigation implementation, for future users and all others taking part in irrigation project alike. The pilot-project enables fast evaluation of the relationship between costs and economical justification of introducing irrigation systems, testing of irrigation effects on the environment, researching various irrigation methods, and so on. It also involves further education of all parties involved in the irrigation process and secures basis for passing regulations regarding the construction, maintenance, and management of irrigation systems.

The Osijek Conty Irrigation Plan was made in accordance with all existing documentation on state level regarding irrigation together with other existing regulations. Suggested technical solutions are based on development studies of water management in the County area in different basins, at the same time taking into account protection of the environment.

It is evaluated that the basic goal of making Osijek County Irrigation Plan (defining guidelines, criteria, and limitations for planned irrigation development in the County with respect to the present and future production conditions, as well as the available natural resources) is fulfilled and that it represents a quality basis for irrigation development. 


\section{REFERENCES}

1. Ayers R.S., WeStcot D.W., 1985. Water quality for agriculture. Rome, FAO Publ., 29.

2. BONACCI O., 2003. Ekohidrologija vodnih resursa i otvorenih vodotoka. (Ecohydrology of water resources and open watercourses). Split, Faculty of Civil Engineering and Architecture: 487.

3. Convention on Cooperation for the Protection and Sustainable Use of the Danube River, 1996. Official Gazette, 2.

4. Directive on Water Classification, 1998. Official Gazette, 77.

5. Helsinki Convention, 1996. Official Gazette, 4.

6. Law of nature protection, 2005. Officiel Gazette, 70.

7. Osijek county irrigation plan, 2005. Osijek, Hidroing.

8. PletiKAPIĆ Z. et al., 2003. Plan upravljanja Parkom prirode Kopački rit. (Management plan for Nature park Kopački rit. Zagreb, Elektroprojekt.

9. Regulations on the establishment of sanitary water source protection zones, 2002. Official Gazette, 55.

10. Nacionalni projekt navodnjavanja i gospodarenja poljoprivrednim zemljištem i vodama Republike Hrvatske (National Irrigation Master Plan of Republic of Croatia), 2005. Ed. D. Romić. Zagreb, Faculty of Agriculture.

11. Strategic basis for water management in Croatia, 2005. Zagreb, Hrvatske vode.

12. TADIĆ L., BAŠIĆ F., 2007. Utjecaj hidromelioracijskog sustava navodnjavanja na okoliš. (Environmental impacts of irrigation). In: Ameliorative measures aimed at rural space development. Zagreb, Proc. Symp. Croatian Acad. Sci. Arts: 173-190.

13. TADIĆ L., TADIĆ Z., MARUŠIĆ J., 2007. Integrated use of surface and groundwater resources in irrigation. Pavia, Italy. Proc. $22^{\text {nd }}$ Eur. Reg. Conf. ITAL-ICID: 33.

14. TAdić L., OŽANIĆ N., TADIĆ Z., KARleuŠA B., ĐuROKOviĆ Z., 2007. Razlike u pristupima izradi planova navodnjavanja na području kontinentalnog i priobalnog dijela Hrvatske. (Differences in irrigation plans in the continental and coastal Croatia). Hrvatske vode 60: 201-212.

15. TADIĆ Z., TADIĆ L., 2003. Wetland management - challenges and prospective. Intern. Conf. GIS Remote Sens. Hydrol. Water Res. Env. Proc. on CD, China.

\section{STRESZCZENIE}

\section{Przykład zintegrowanego wykorzystania powierzchniowych i podziemnych zasobów wodnych do nawodnień w Chorwacji}

Słowa kluczowe: plan nawodnień, środowisko, zasoby wodne, zintegrowana gospodarka wodna

Do niedawna problem nawodnień w produkcji żywności w Chorwacji, szczególnie w jej kontynentalnej części był zaniedbywany. W ciągu ostatnich 50 lat ważniejszy był rozwój systemów drenarskich w związku z powodziami i nadmiarem wody na polach uprawnych. W ostatniej dekadzie reżim hydrologiczny uległ zmianie i susze stały się równie częste, jak powodzie, powodując nawet większe straty. Przyszły rozwój rolnictwa w północnych powiatach Chorwacji zależy od wprowadzania nowych zyskownych upraw, co implikuje stosowanie nawodnień jako czynnika istotnego dla społecznego i gospodarczego wzrostu. 
Pierwszym etapem wdrażania nawodnień było stworzenie Narodowego Planu Nawodnień jako ramy dla przyszłej działalności.

Zgodnie z zaleceniami Narodowego Planu wszystkie powiaty stworzyły Powiatowe Plany Nawodnień, uwzględniające miejscowe warunki naturalne oraz zaplecze społeczne i gospodarcze.

$\mathrm{W}$ artykule przedstawiono, jak rozwija się proces zintegrowanej gospodarki zasobami wodnymi w kontynentalnej części Chorwacji na przykładzie „Planu nawodnień powiatu Osijek, usytuowanego w dorzeczu Dunaju.

Reviewers:

Prof. Waldemar Mioduszewski

Prof. Edward Pierzgalski 